\title{
一綜 説一
}

\section{腎 結 石手 術 \\ 秋元 成太* \\ 日本医科大学泌洜器科学教室}

\section{はじめに}

腎結石に対する腎保存手術の意義は，できるだけ腎 機能の盜存をはかったうえで，残石がないように腎結 石を完全に除去する点にある.

腎結石症例では，閉塞性尿路障害のほかに，腎㹂 炎を合併しているものも少なくなく，治療方針の決定 については保存手術の適応の有無について常に留意し でく必要がある.

腎結石の手術法については, (1) 体外腎手術法（ex vivo 法) と(2)体内留手街法 (in vivo 法) があるが, (1)の適応と考えられるものは少なく，(2)が通常施行さ れている.乙かしながら， in vivo 法においても術中 各種の補助的手段が案出されており，それはまた，そ れはど腎結石手術を目的ど扔り行うには困難を伴うこ とが多いということの証拠でもある。

この補助的手段には，孯盂切石術 (pyelolithotomy) との併用で発達してきた結石を固定, 捕捉するための fibrin coagulum を利用した方法, 腎阻血時に腎機能 の保持を目的とした体内腎冾却法 (in situ renal hypothermia), 経皮的腎切石術 (percutaneous nephrolithotomy）などがあげられるが，順を追って述べてみ たい.

1. 腎睢切石術 (pyelolithotomy), 腎切石術 (nephrolithotomy), および腎部分切除術（partial nephrectomy)

腎盂切石術は，腎血管 clamp による腎阻血を伴わ ないで行えるほか, 呰周囲脂肪織などを完全に剝離せ ずに，腎盂のみを露出すればよいという利点があり， したがってほかの術式に比較して腎実質に与える影響 は最も少ない。

この術式の進歩, 改良はほぼ Gil-Vernet ${ }^{1)}$, Blandy ら゙によるものに代表されていると考えてよいが，堅
孟切開を延長して大きい結石までを取り出せる，いわ ゆる㹡大腎孟切石術 (extended pyelolithotomy) と 名付けられる術式である。しかしながらここの方式の みでは拉張した腎杯中に多数の小結石を伴うような鋳 型結石に対しては，好成績を上げるのは困難である.

腎切石術は，結石の完全除去を目的として行われて いると考えてよいが，腎実質切開による出血量を少な くし，十分な視野を確保するために，㫮盐切石術と同 様汇改良，進歩が重礼られてきた. 代表的なのは， Boyce $ら^{8)}$ にる anatrophic nephrolithotomy であ るが，これは解剖学的にみて，血管分布がほとんどな いと考えられている後面で，Brödel line" といわれる 筍所を切開する方法である (Fig. 1).

Boyce ら ${ }^{83}$ は，この方法に加えて，さらに後述する 腎泠却法を併用して優れた成續を上げているが，われ われの追試では多発性に存在する前面の腎杯結石を完 全に除去するのに困難がある.結局のところ，狭い infundibulum 内で，しかも抗張した腎杯内結石除去 を試みるには，Fig. 2 に示すような Wickhamの paravascular multiple nephrotomy を行わざるをえ ない症例を経験するのが寒情である.

腎部分切除術はその利点として, 結石形成化最も関

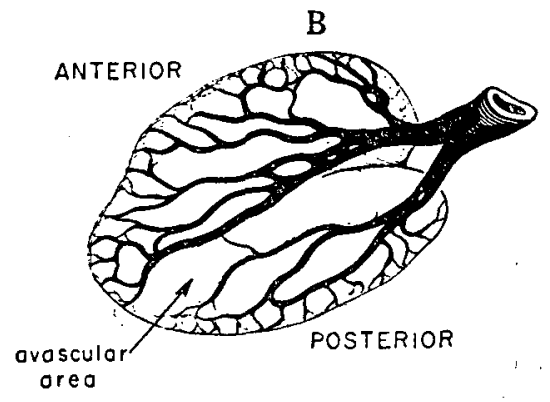

Fig. 1 Brödel line

(from Kerr, W.S., Jr. : Surgical management of renal stones with emphasis on infundibulotomy. J. Urol., 103, 130 133, 1970) 


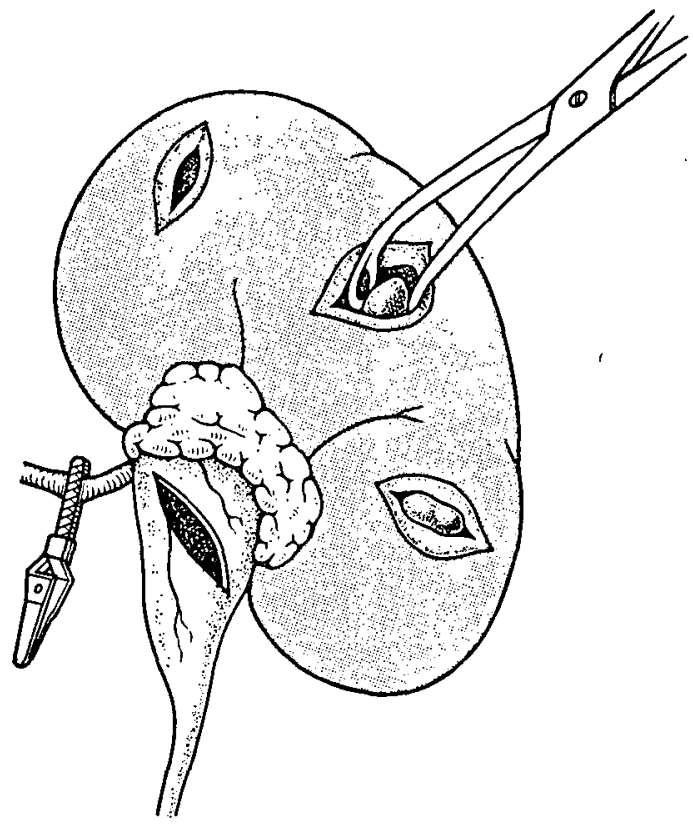

Fig. 2 The multiple dissection nephrotomy, nephrolithotomy

(from Wickham, J.E.A. : Paravascular multiple nephrotomy : Stones clinical management of Urolithiasis, p. 340, Williams \& Wilkins, Baltimore, 1983)

連すると考えられる lithogenous focus の除去が可能 である点が強調される。しかしながら，㹂実質切除に よる腎機能低下のほか，堅血管 clamp に上る阻血の 影響が加わるので，慎重に適应症例を選ぶ必要があろ 5 .

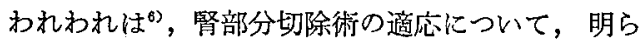
かな腎杯拡張が瑟められないような症例であっても， (1)下繁杯に多発した結石で，(2)長期間にわたって尿路 感染が認められるようなときには，最下腎杯の切除を 含む腎部分切除術の適応があるもの亡考えている.

高井 ${ }^{7}$ は，腎部分切除術のほうが腎切石術に比較し て結石再発が少ない点について，発生部位と考えられ る腎乳頭部が切除されるほか，特に下腎杯に多発性結 石をみる際には，水力学的意味で下腎杯に尿の停滞を 起こしている可能性が高く，したがって結石再発の点 からみると，この下腎杯を含めた乳頭部切除後縫縮す ることは，再発結石が滞留しなくなることから，侵繁 が大きく残存腎機能の低下という久点を補ってもさら にあまりある方法だと述べている。

しかしわれわれ ${ }^{6.8)}$ の術式別再発率 は, 腎昷切石術 20\%，腎切石術 $21.4 \%$ ，腎部分切除術 $18.5 \%$ であ
り，術式間に著明な差はみられていない。さらに 最近の症例を追加して検討し，報告したい，なお 以上の成績は，anatrophic nephrolithotomy を行 った Redman ら の) 21\%, pyelolithotomy を 行った Blandy ら ${ }^{10)} の 20 \%$ 上ほぼ同様な結果 であった.

\section{Coagulum を利用した留結石手術}

1943 年, Dees ${ }^{11)}$ が基礎的検吋に加えて, fibrin coagulum の臨床的応用の可能性について 追究し，この分野での先駆的業續を発表してい る. 彼は腎結石に対する coagulum 使用のため の条件として次の7項目を挙げた。 今日に至って も，ほぼこれらの条件は必要であると考えられる ので列挙してみる.

(i) coagulum は，腎䀃に注入可能で，十分 に充満させることができる液体であること．

（ii）短時間で均一な coagulum となりうるこ とただし coagulum 形成前に腎杯を充満させ るための時間的余裕は必要である.

(iii) coagulum の性状は，短時間で十分な張 力をもつようになるべきで，乙かむどんな形の結

石をも取り込んで引き出せるような張力でなけれ ばならない。

（iv） coagulum は，満足すべき伸展性と弾力性を むち，扔のおのの腎杯の型どおりに，狭い infundibulum を通して引き抜けるべきであり，腎盂の小切 開ですべての coagulum が除去できなければならな W.

（v） coagulum は，腎に対して障害があってはな らない.

（vi）仮に coagulum の一部が腎盂腎杯内または腎 実質内に残っても，異物とはならないで，それが数日 間で溶解か分解されるものでなければならない。

(vii) coagulable substance の性質として，わず かの尿あるいは血液と接触または混合しても，影響を 受けないるのでなければならない。

以上であるが，(iii)，(iv) についてはまだこの条 件を十分に満たするのは出現しておらず，むしも満足 するものであれば完全な coagulum といってよい。

この方法は，むしろ適応決定に問題があるが，臨床 応用上 Patel は適応を拉大して, 次のような方法を推 奖している．簡単に紹介すると，coagulum 㫮盖切石

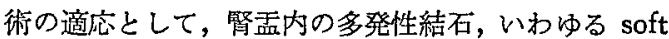


and crumbly stones のほかに，腎杯内結石をも対象 とし，腎部分切除術や腎切石術を行う前に，結石固定 (fixation) の目的で coagulum を注入する方法を推 奖している，確かに，腎杯の多発性小結石では，腎操 作中ほかの腎杯への移動によって残石として取り残す 可能性があり，それを防ぐ意味でもこの方法を行うこ との意義はあるものと考えられ，われわれ ${ }^{12)}$ この方 法を行っている.

次に，われわれの coagulum 作製方法について述 べるが，手術場での操作であるので，できるだけ“誤 る操作が少なく, しかも一定の張力が得られる”簡単 な方式を採用している.

fibrin coagulum の注入方法を簡略に述べると，ま ず最初に尿管を軽く圧迫閉塞しておいて, 腎孟切開口 より排尿させた後, 生食水を注入し, 腎盂腎杯内の容 量を測定しておくこの容量よりやや多量のヒトフィ ブリノーゲンとトロンビンを用意する. すなわち, 室 温に挨いてヒトフィブリノーゲン $1 \mathrm{~g}$ を生食水 $20 \mathrm{ml}$ の比に溶解するのであるが，このとき完全に溶解する には約 10 分を要することを知っておくと便利であ る. これを Fig. 3 に示すように, 三方活栓をつけ た注射筒の一端Aにつけておく、ほかにトロンビン 580 単位を生食水 $20 \mathrm{ml}$ に溶解し, 三方活栓の他方 Bに接続しておく.この A と B の混合比を 4: 1で coagulum 作製を行っている. 注入方法は, 腎孟外で

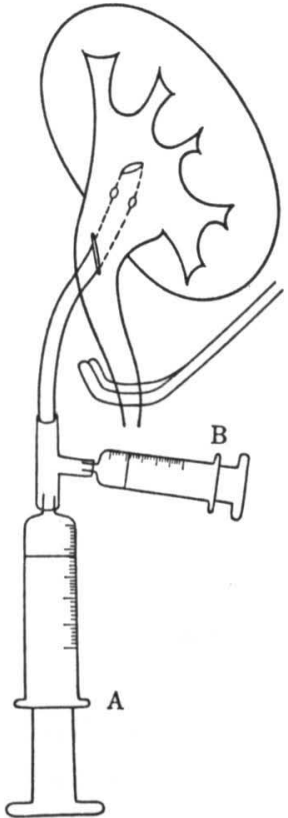

Fig. 3 Instillation method of fibrin coagulum

両液を混合して直ちに注入するが，この操作を手間取 ると注射筒内で凝固する危険がある.この方法での腎 孟腎杯内での凝固時間は約 2 分 30 秒である.

最近アメリカでは, 肝炎発生の危険のない cryoprecipitation fibrinogen を使用して, 十分な張力をもつ

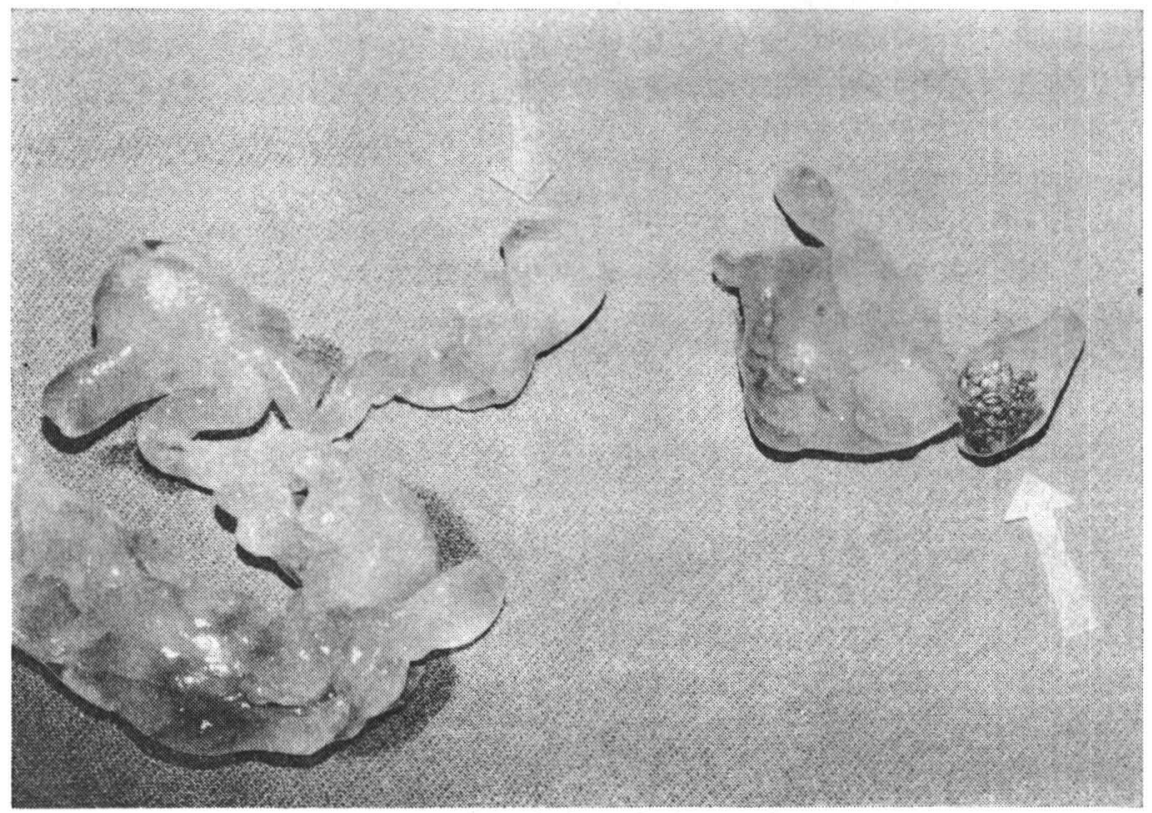

Fig. 4 Multiple small calculi in fibrin coagulum 


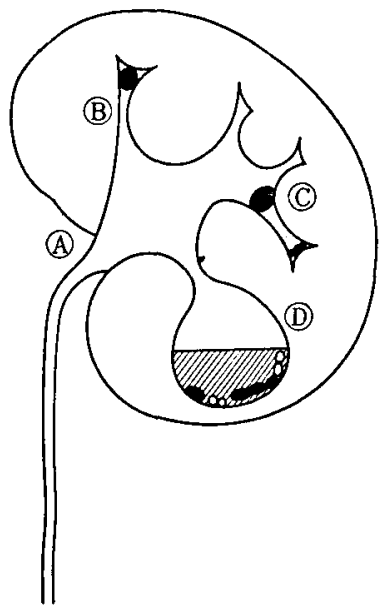

Fig. 5 Schema of fibrin coagulum pyelolithotomy in difficulties

coagulum を作製しているが，高価なのが久点であ り，われわれの経験ではヒトフィブリノーゲンが原因 と考えられる肝炎の発生はまだない。 coagulum が捕 捉した多数の小結石を Fig. 4 に示す.

前述したと㕲り，本方法がすべての腎結石に有効で あるとはいえないし，むしろ小結石であっても，結石 除去困難例, 寸なわち適応外症例を知っておくことが 腎結石手術の手術法選択の上できわめて重要なことで ある。

Fig. 5 に示すごとく, (A)では腎外腎孟が小さくて, coagulum 腎盘切石術では結石捕捉はできない.しか し結石固定を目的として, 留切石術, 留部分切除術を 併用して，好結果を上げることは可能である.

(Bよよに infundibulum が狭く，その先に 結石 が存在するときは， coagulum で捕捉しても結石を引 き出すことは不可能である. (Cは結石が重なってい $\tau$, infundibulum を閉塞し, 登杯の結石には coagulum が到達できず，したがって除去はできないが， 繁䧴さをいとわなければ，理論的にみて 2 回施行すれ ば除去は可能である. (Dでは拉張した腎杯に多発性小 結石が存在しており，その著明な搪張によって腎杯内 の尿を十分に吸引できず，したがって coagulum は 到達不能となる。ただし，結石固定を目的として， coagulum 注入後, 腎切石術や腎部分切除術を併用寸 れば，拉張腎杯よりの結石の逸脱を防いで，除去する ことは可能である.

ただし，われわれの経験外のことではあるが，最近 になって注意すべき報告がなされているのは，腎盖を coagulum で高度に抾張すると coagulum が血中に 入って血栓を起こす点であり，われわれも以後十分に 留意すべきであると考えている.

\section{3. 冷却下体内腎結石手術 (Renal surgery of in} situ hypothermia for nephrolithiasis)

腎切石掞よび腎部分切除術を行う際の腎機能に影響 を与える因子として，留实質の切開，䣄合のほか，腎 阻血を考慮することがきわめて重要であるのは諭をま たない。

臨床的には腎手術時，永久的腎細胞障害をわずかで も残さないようにするには，腎阻血時間は 30 分以内 とされている，また，すでに筒疾患があるときは，厳 しい時間的制限が必要であるのは当然であろう。

in situ hypothermia の方法は, われわれ18)が行っ ている，(1)腎表面の冷却を行う external parenchy. mal cooling（surface cooling）のほかに，(2)腎動脈内 に冷却した灌流液を注入する perfusion cooling が ある. 泌尿器科領域ではほとんど行われないが，(3)全 身を低体温下にすることで 2 次的に腎温度低下を目的 とする whole body hypothermia もまれには報告さ れている.

(1)の external parenchymal cooling の方式でも， 多種多椂の工夫，改良した装置の発表がみられる，例 えば, Cockett $ら^{142}$ の stainless steel cooler, Wickham $ら^{15)}$ の coobling coil は，多数の臨休例に応用されて 好成績を上げている.また，(2)の perfusion cooling 法にしても，各種の方式が報告されている．まず考え られる方法として, Wagenknecht $ら^{(6)}$ は腎動脈へ灌 流液を持続的に注入し，觜実質灌流後，腎静脈に返す 方式で行っている. Mareković ら ${ }^{12}$ は，腎静脈に彼 らが考案した 2 孔のカテーテルを擂入し，一方より冷 却 solution を注入して他方より排出するといら方式 で，腎実質温度を $20^{\circ} \mathrm{C}$ 以下にできたという。

腎阻血時の最適泠却温度については，必ずしもす心゙ てに認められている訳ではないが，Luttrop ら ${ }^{18)}$ の子 ブタの腎を使用しての実験で，hypothermia 下の腎 阻血で $16 \sim 18^{\circ} \mathrm{C}$ が最もよい腎保存成績が得られたと いう報告があり，彼らは 3 時間以内の腎阻血であれ ば，16〜18 ${ }^{\circ} \mathrm{C}$ に維持できれば糸球体および 尿細管機 能は十分に保持できたとしている.

ここで，われわれの行っている external parenchymal cooling 法について紹介する.

まず，5\% mannitol $500 \mathrm{ml}$ を術前に点滴静注して 
Table 1 Renal surgery for complicated nephrolithiasis under in situ hypothermia

\begin{tabular}{|c|c|c|c|c|c|c|c|c|}
\hline & name & $\operatorname{sex}$ & age & site & operation method & $\begin{array}{l}\text { ischemic } \\
\text { time (min) }\end{array}$ & $\begin{array}{l}\text { residual } \\
\text { stone }\end{array}$ & Postoperative IVP \\
\hline 1. & S.K. & 우 & 47 & 1 & $\begin{array}{l}\text { partial nephrectomy } \\
\text { + nephrolithotomy }\end{array}$ & 80 & - & improved, mild \\
\hline 2. & I .M. & s & 35 & 1 & partial nephrectomy & 78 & - & improved \\
\hline 3. & K.M. & 우 & 8 & 1 & nephrolithotomy & 75 & - & improved \\
\hline 4. & H.O. & $\hat{o}$ & 32 & $\mathbf{r}$ & nephrolithotomy & 31 & - & no change \\
\hline 5. & K.S. & $\hat{o}$ & 32 & $r$ & nephrolithotomy & 51 & - & improved, mild \\
\hline
\end{tabular}

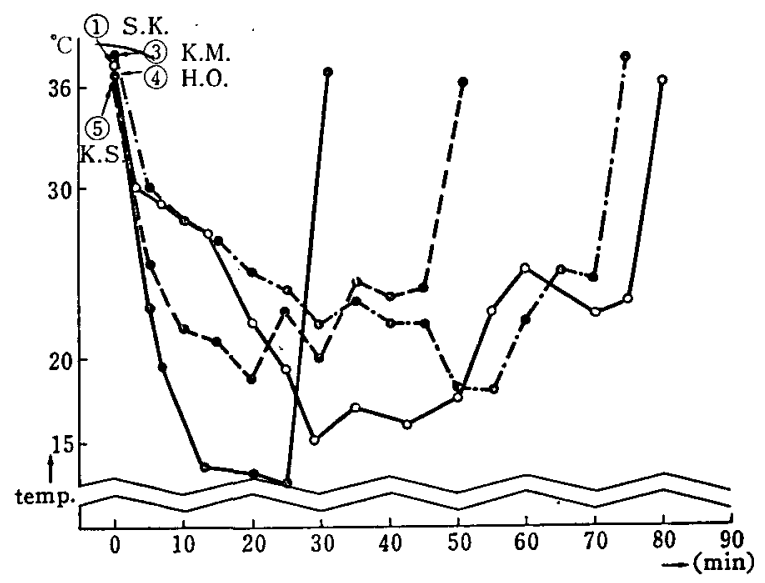

Fig. 6 Changes of renal temperature under in situ hypothermia

おくことが望ましい，腎動脈を clamp した後，固定し ておいた plastic sheet で腎をくるむように巻きつけ， 腎と plastic sheet の間に slushed iced saline or slushed lactate linger 定入れる。この際，腎実質 内温度測定を行っているが, $1.5 \mathrm{~cm}$ の深さに thermister probe を挿入している. 1979 年 9 月までの自験 5 症例を Table 1 に, うち 4 症例の温度変化を Fig. 6 に示す.われわれの方式中，注意すべき点と して，腹膜を介して腸管に与える冷却の悪影響を考虑 すべき点が挙げられるが，通常は plastic sheet と腹 膜の間にタオルを挿入して腸管を保護している.

perfusion cooling 方式では，督莛部よりカテーテ ル插入を行うのに必要な腎茎部を露出するための剝離 が必要であり，さらに挿入，排出の 2 管は通常視野を 妨げるのと，その保持に留意しなければならないのが 欠点であるう。この久点を補うために，大腿動脈より カテーテルを挿入して solution を灌流させ，腎を冷 却させようとする試みはあるが，実際に行われる症例 が少ないのは実施するのが繁雑で，技術的には困難で あるからだといわれている。
一方, external surface cooling の久点は, 水 が同一部位に長時間接触するために起こる,いわ ゆる frost bite の久点がある. Graves ${ }^{19)}$ は cooling medium を plastic bag に入れ，その bag で腎を包む方式による in situ hypothermia を試 みたが，長時閒の腎阻血が腎組織の生物学的活性 を下げる可能性が大きいとし，さらに proximal convoluted tubules は酸素久侯に敏感であるとも 主張している.この proximal convoluted tubules は腎表面に近い部位に存在し， surface cooling による温度変化の影響を受けやすい位置にあるの で，その影響を軽減する目的で，30\%グリセりン を含む cooling medium を併用し, いわゆる hypothermal burns と patch necrosis 発生の危 険性を少なくしたという.

腎手術時の薬物効果については，まず mannitol に 対する評価は相反するものがあるが，浸透圧作用を利 用して問質の浮腫と組織内圧上昇を防ぎ，尿細管に対 する保護的役割を考えて，使用する意義があるとする 肯定的論文が否定的論文より多いようである. inosine の效果についても, その有效性を認める報告が散見さ れるが, 今後さらに投与方法, 投与量を含めて十分な 検討がなされ，臨床的使用の意義についても正しい評 価がなされるであろう.

なお付け加えれば，手術時間短縮を目的として， Redman ら は腎阻血方法として, Boyce らの腎動脈 のみを clamp する方法は虽㕍露出に時間を要すると し，Satinsky 血管鉗子で腎動静脈を集束的に圧迫阻 血しても腎機能に与える影響には差がみられないとし ている.また, collecting system を繨合閉鎖しなく ても好成績は上げられるとし,より簡略化した術式を 行って督阻血時間の短縮も試みている.

以上のように，術式の改良，進歩は目覚ましいもの があり，われわれす今後さらに努力を重ねて，十分な 補助的手段を活用しながら腎機能維持をはかりつつ, 
腎結石手術を行いたいと考えている.

\section{4. 経皮的堅切石術 (Percutaneous nephroli- thotomy)}

最近，各科領域で内視鏡が目を見張るような進歩を 遂げているのは，誰もが等しく認めるところであろ う.これは必尿器料頒域に扔いて例外ではなく，わ れわれも本方式を採用して臨床的経験を稹み，現時点 に招けるこの方法の適応，評価を行ってきた．教室の 戸塚，西村ら ${ }^{200}$ は，先駆的な仕事をしている．現在， 用いられている手技方法は一様ではないが，その 2 ， 3を紹介する。

まず，経皮的腎瘦造設術は DIP 施行，局麻透視下 にて行い，dilator にて应張しておく. 西村 ${ }^{20)}$ の経験 では，次のような方式に分類される.

(1) カテーテルと銝子の組み合わせ

透視下にて，ガイドワイヤーを腎瘦より目的とする 場所まで挿入し，次いで使用する鉗子(stone grasping forcepts またはバスケットカテーテル)を挥入し， 結石捕獲を試みる方法である.この方法は，透視下で の操作のため，尿管へのガイドワイヤーの挿入は比較 的容易ではあるが，腎杯に対しては立体的位圈がつか みにくく，目的とする腎杯一の到達が難しい，

(2) 内視鏡と鉗子の組み合わせ

1）気管支ファイバースコープ

腎瘦より腎盂化㨀入し，鋁子口上り灌流液を注入し て視野の改善をはかりながら結石を確認し，同し錋子 ロより銘子を挿入して結石を捕獲する。この方式での 問題点は，1 チャンネルで灌流液による腎盖の洗浄や 拡張と，鉗子操作を同時に行うことができず，鉗子操 作中に十分な視野を得るのが難しい点である.この際 には，逆行性に㽷管カテーテルを描入し，灌流液によ る洗浄を行い鮮明な視野を得ることができる.

2) ネフロスコープ

現在のところ, 経皮的操作が可能な長さのネフロス コープは日本製のものしかなく，耐久性に疑問がある ほか, 弯曲度が低いといら久点がある.

3）膀胱鏡ファイバースコープ

堅瘦より小児用または成人用膀胱鏡を挿入し，灌流 しながら鈷子で主として腎揫結石を対象として捕獲す る.この方法の利点は, 最も鮮明な視野が得られ，鉗 子操作中に十分灌流を行えることであるが，ほとんど 角度がつけられないため，督孟結石除去にはよいもの の，䟧杯結石に対する操作には限界がある.
以上，本方式での手技上の問題点を検討してきた が，経皮的腎切石術の利点として，西村ら ${ }^{200}$ の述べる

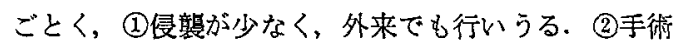
既往のある患者にも容易に行いうる，といら点が挙げ られる。 また，以上のほか，(3)督瘦造設が簡単にで き，直ちに疝痛が消失する. (4)腎貿通過可能な大きさ の，㫮盂また慳孟尿管移行部結石の除去には最も適 応がある，といら点も挙げられよう。

\section{5. 腎摘除術 (Nephrectomy)}

腎摘除術は，完成された術式といってよく，この術 式による死亡率は近年著明な低下を示している。むし 万問題点は，緊結石に対する腎摘除術の適虑をどこに おくかであろう．結石による水腎症においては，炎症 の合併を十分に考慮に入れる必要がある。督結石につ いて，督摘除術施行例のわれわれ21)の retrospective な検討では，高度の水腎を示した群および造影剂の排 泄が全く認められない群では，進んだ形の炎症すなわ

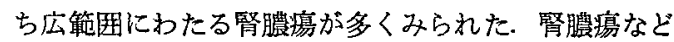
の炎症との合併は; 高度の水腎症群では $60 \%$, 排泄が 認められない群では 8296 にも達していた すなわち， 結石による閉塞性督障害 (obstructive nephropathy) では，尿路感染との合併がきわめて高率们認められる ということであり，相互に及ぼす悪影響について十分 考慮されるべきである.

結局，腎摘除街の適応として参考にすべきは，(1)水 腎症の程度，持続期間，(2)腎感染の有無，程度，持続 期間，(3)分祭機能検查，(4)合併症（特に内科的合併 症)であり，個々の症例につき，慎重に考慮すべきで あろう。

以上，緊結石手術につき，当泌尿器科教室での経験 例を参考に若干の文献的考察も含めて述べた。

\section{文 献}

1) Gil-Vernet, J.M. : New surgical concepts in removing renal calculi. Urol. Int., 20, 255 288, 1965.

2) Blandy, J.P., and Tresidder, G.C. : Extended pyelolithotomy for renal calculi. Br. J. Urol., 39, 121 130, 1967.

3) Boyce, W.H., and Elkins, J.B. : Reconstructive renal surgery following anatrophic nephrolithotomy; Follow up of 100 consecutive cases. J. Urol., 111, 307 312, 1974.

4) Brödel, M. : The intrinsic blood vessels of the kidney and their significance in nephrotomy. Bull. Johns Hopkins Hosp., 12, 10 24, 1901.

5) Wickham, J.E.A. : Paravascular multiple nephro- 
tomy; Stones clinical management of urolithiasis. (Roth, R.A., and Finlayson, B. eds.), Williams \& Wilkins, Baltimore, 1983.

6）秋元成太，庴野晴彦，近喰利光，川井博 : 腎手術につ いての臨床的検討. 第 1 報 蜸部分切除術について。 臨泌, 30, 1033 1038, 1976.

7）高井修道：腎部分切除術. 臨泌，21，217 221，1967.

8）秋元成太, 中島均, 由井康雄, 戸塚一房, 矢崎恒忠, 金森幸男，奥村哲，大場修司，高橋茂樹，西川源一郎， 吉田和弘, 西村泰司, 富田勝, 近喰和光, 川井博 : 腎 手術についての臨床的検討. 第 2 報 腎切石術および 筲孟切石術. 臨泌, 32, 239 244, 1978.

9) Redman, J.F., Bissada, N.K., and Harper, D.L. : Anatrophic nephrolithotomy; Experience with complications of the Smith and Boyce technique. J. Urol., 122, 595 597, 1979.

10) Blandy, J.P., and Singh, M. : The case for a more aggressive approach to staghorn stones. J. Urol., 115, 505 506, 1976.

11) Dees, J.E. : Use of intrapelvic coagulum in pyelolithotomy; Preliminary report. South. Med. J., 36, $167 \sim 175,1943$.

12）秋元成太, 富田勝, 平岡保紀, 坪井成美, 由井康雄, 中島均，大場修司，奥村哲，吉田和弘，西村泰司，川 井博 : 腎手術についての臨床的検討. 第 4 報 腎結石 に詨寸る fibrin coagulum の利用. 臨汼, 35, 863 $869,1981$.

13）秋元成太, 坪井成美, 由井康雄, 中島均, 戸塚一彦, 奥村哲，金森幸男，大場修司，吉田和弘，西村泰司， 富田勝，川井博：腎手術の臨休的検討。第 3 報 In situ hypothermia 下での腎結石手術. 臨泌, 34, 555 $\sim 561,1980$.
14) Cockett, A.T.K., Davis, R.S., and Linke, C.A. : Intra-renal and Kidney workbench surgery under hypothermia. "Abstracts of 18th International Urology Congress", p. 105, Paris, 1979.

15) Wickham, J.E.A., Hanley, H.G., and Jokes, A.M. : Regional renal hypothermia. Br. J. Urol., 39, $727 \sim 743,1967$.

16) Wagenknecht, L.V., Hupe, W., and Büeheler, F. : Selective hypothermic perfusion of the kidney for intra renal surgery. Eur. Urol., 3, 62 68, 1977.

17) Mareković, Z., Vukinovac, M., Kalauz, N.O., and Pasini, J. : Renal hypothermia in situ by venous passages clinical experience. "Abstracts of 18th International Urology Congress”, p. 119, Paris, 1979.

18) Luttrop, W., Nelson, C.E., Nilsson, T., and Olin, T. : Study of glomerular and tubular function after in situ cooling of the kidney. J. Urol., 115, 133 $135,1976$.

19) Graves, F.T. : Renal hypothermia using peripheral cooling with glycerine solution. "Abstracts of 18th International Urology Congress", p. 115, Paris, 1979.

20）西村泰司，舆村哲，吉田和弘，开塚一彦，中島均，秋 元成太 : 経皮的腎尿管切石術; 特に手技上の問題点に ついて. 臨泌, 37, 323 327, 1983.

21）秋元成太，奥村哲，大場修司，吉田和弘，平岡保紀， 西村泰司，富田腾，川井博：腎手術の臨休的検討. 第 5 報 上部尿路結石に対士る腎摘除術施行例について の retrospective な検討. 臨泌, 36, 39 43, 1982 ,

（受付：1983 年6月13日） 